\title{
Economic Integration, Non-tariff Barriers and Social Welfare
}

\author{
Aitor Calo-Blanco \\ University of Alicante \\ José Méndez Naya \\ University of A Coruña
}

\begin{abstract}
This paper analyses the extent to which preferential trade agreements can lead to the substitution of non-tariff barriers for tariffs, and the effects of non-tariff barriers on welfare and other parameters. Its main results are that non-tariff barriers reduce aggregate welfare, and that the governments of economically integrated countries replace tariffs by non-tariff barriers if and only if their priority is protection of their nations' firms.
\end{abstract}

- JEL Classifications: F12, F13, F14

- Key words : Economic integration, Commercial policies, Tariff and nontariff barriers

\section{Introduction}

Until the work of Viner (1950), it seems to have been generally assumed that economic integration in trade blocks is always beneficial, on the grounds that the removal of trade barriers between the countries involved allows more efficient location of resources and is a step towards worldwide free trade. Viner argued that

\footnotetext{
*Corresponding address: José Méndez Naya, Facultad de Ciencias Económicas y Empresariales, Campus de Elviña s/n, University of A Coruña, 15071 A Coruña, Spain, Tel: +34-981-167000, Fax: +34-981167070: E-mail: jmn@udc.es, Aitor Calo-Blanco, Facultad de Economicas, Dpto. Fundamentos del Analisis Economico, Carretera de San Vicente s/n, 03080 San Vicente (Alicante), Spain, Tel: +34-96590-36-14 (ext. 2535), Fax: +34-96-590-38-98, E-mail: aitor@merlin.fae.ua.es (C2005-Center for International Economics, Sejong Institution, All Rights Reserved.
} 
the overall effect of local integration can actually be either beneficial or deleterious, since the creation of trade within the block may be counteracted by a reduction of trade with countries outside the block. Although Kemp and Wan (1976) suggested that a beneficial outcome can be ensured by member countries setting their external tariffs at levels that guarantee the maintenance of trade with non-member countries, the fact is that member countries generally have no incentive to behave in this way, since it reduces their welfare.

In spite of Vine's arguments, the economic integration of groups of developed or developing nations has accelerated throughout the world, resulting in the lowering or elimination of import duty barriers within these blocks. It has been accompanied, however, by an opposing trend: the introduction of non-tariff barriers which, like the tariffs they replace, aim to protect countries' own producers from foreign competition in the national market (Daly and Kuwahara 1998). For example, Neven and Röller's (1991) finding that in the European Union the companies of the home country always had larger shares of the domestic market than EU firms of other nationalities was considered by these authors as possibly being due not only to consumer preferences but also to foreign firms having higher costs because of non-tariff barriers (although non-tariff barriers hindered trade with non-EU countries more than trade within the EU). Here we use the term "non-tariff barriers" in a broad sense, including both legal measures and administrative procedures based on the informal directives of governments and other institutions. Such barriers can be very diverse in nature, among the most important being customs procedures and controls, health and safety regulations, packaging and labeling regulations, environmental and ecological regulations, control of exchange rates, exportation limits imposed by importing countries, importation quotas, discrimination by governments acting as suppliers, and state aids such as subsidies and tax benefits (Sanna-Randaccio 1996); but they all have in common that they favour national products over foreign competitors (regardless of whether the latter originate within or outside the trade block in which the home country is integrated), and many are non-transparent and difficult to find out about, interpret and satisfy. Daly and Kuwahara (1998) classify them in two major groups: quantity restrictions and price control measures. The practices of particular countries in this respect have been the subject of several studies; see Daly and Stamnas (2001) for the case of South Korea, for example. Awareness of their effects has led to their elimination becoming an important objective of recent trade agreements.

The introduction of non-tariff barriers has been the object of several analyses. 
Winkelmann and Winkelmann (1997) reported evidence that their costs are higher than was once usually supposed. Yu (2000) concluded that governments trying to balance the interests of business and consumers (i.e. voters) will nevertheless be willing to favour the former by introducing non-tariff barriers because their priceraising effects are less evident to the general public than those of tariffs. It is necessary, however, to distinguish between traditional exporters based in the home country and multinational firms capable of direct investment in plant in foreign countries (Sanna-Randaccio 1996); the preference of multinational firms for exports to or direct investment in a particular foreign country, and the consequent effects on welfare in both countries, will depend on the kind and extent of the barriers to trade between them. In the case of Switzerland, Grether and Müller (2001) argued that integration in the European Union would be beneficial because of the lowering of non-tariff barriers.

To analyse the extent to which countries engaged in a process of economic integration might have incentives to introduce non-tariff barriers, in this paper we use a two-stage game model, in which trade policy setting is followed by Cournot competition among firms, to examine the effects of non-tariff barriers on national aggregate welfare in various situations involving different degrees of integration. Our main conclusion is that countries that are members of a customs union should not establish indiscriminatory non-tariff barriers unless their priority is not national aggregate welfare but the protection of their own companies. The implementation of such a policy through "delegation" has been discussed by several authors, including Collie (1997) and, in the context of a customs union, Lipsey (1970), who concluded that if there are mechanisms for transfer of welfare among member states then the common policy on trade with non-member states should maximize union-wide aggregate welfare; in the absence of welfare transfers, it has been argued that the interests of member states would clash because all would try to maximize their own welfare (Riezman 1985).

\section{The Model}

Like Brander (1981), we consider a homogeneous good produced with constant returns to scale and with no limits on quantity by three different firms, one in each of three countries (1,2 and 3). Under these conditions the total market for the good is segmented, that is, from the point of view of producers the markets of the three countries are independent of each other. We consider the market of country 3 
(market 3), and, in order to simplify the analysis, assume that the marginal costs of country 1's firm are zero, and that those of the firms of countries 2 and $3\left(c_{2}\right.$ and $c_{3}$, respectively) satisfy $c_{3}>c_{2}>0$.

Denoting by $x_{i}$ the quantity sold in market 3 by the firm of country $i$, defining $q=x_{1}+x_{2}+x_{3}$, and assuming a quadratic consumer utility function $U(q)=a q-1 / 2 b q^{2}$, then the price in market 3 is given by the inverse demand function

$$
p=a-b q
$$

In general, the profits $\pi_{1}$ and $\pi_{2}$ made in market 3 by the firms of countries 1 and 2 , respectively, are given by

and

$$
\begin{gathered}
\pi_{1}=\left(p+s_{1}-t_{1}-n\right) x_{1} \\
\pi_{2}=\left(p-c_{2}+s_{2}-t_{2}-n\right) x_{2}
\end{gathered}
$$

where the $s_{i}$ are unit export subsidies received by these firms, the $t_{i}$ are tariffs imposed by country 3 , and $n$ represents the cost of passing non-tariff barriers; and the corresponding contributions to the welfare of these countries are

$$
W_{1}=\pi_{1}-s_{1} x_{1}=\left(p-t_{1}-n\right) x_{1}
$$

and

$$
W_{2}=\pi_{2}-s_{2} x_{2}=\left(p-c_{2}-t_{2}-n\right) x_{2}
$$

The profit of country 3's firm in market 3 is

$$
\pi_{3}=\left(p-c_{3}\right) x_{3}
$$

and the corresponding contribution to country 3 's welfare is the sum of its consumer excess, the profits $\pi_{3}$ of its firm in this market, and any income from tariffs

$$
W_{3}=U(q)-p q+\pi_{3}+t_{1} x_{1}+t_{2} x_{2}
$$

The economic behaviour of the agents in this general situation is modeled as a two-stage game: in the first stage, subsidies, tariffs and non-tariff barriers are established; in the second, firms engage in Cournot competition, deciding the quantities of the good they will each put on market 3 . The game is solved for its subgame-perfect equilibrium by backward induction.

\section{Analysis of Trade Policies}

In this section we analyse the game described above for four situations representative of different degrees of economic integration:

1) The three countries set their trade policies independently (in particular, 
country 3 does not discriminate between countries 1 and 2 in setting its import duties);

2) country 3 enters into a preferential trade agreement with one of the other countries, that is $t_{1} \neq t_{2}$;

3) the parties to the preferential trade agreement increase their economic integration by forming a customs union; and

4) country 3 introduces non-tariff barriers that do not discriminate between the other two countries.

To ensure that the equilibrium quantities emerging in the analyses are positive, we assume that $a>13 c_{2}-3 c_{3}$ and that $4 a>10 c_{3}-3 c_{2}$.

\section{A. Non-cooperative behaviour with no discrimination between exporters}

In this situation, $t_{1}=t_{2}=t$ and we assume that $n=0$ (since there is no need for non-tariff barriers when tariffs can be imposed). The conditions for Cournot equilibrium are therefore

$$
\begin{aligned}
& \partial \pi_{1} / \partial x_{1}=a-b\left(2 x_{1}+x_{2}+x_{3}\right)+s_{1}-t=0 \\
& \partial \pi_{2} / \partial x_{2}=a-b\left(x_{1}+2 x_{2}+x_{3}\right)+s_{2}-t-c_{2}=0 \\
& \partial \pi_{3} / \partial x_{3}=a-b\left(x_{1}+x_{2}+2 x_{3}\right)-c_{3}=0
\end{aligned}
$$

with the solution

$$
\begin{aligned}
& x_{1}=(1 / 4 b)\left(a+3 s_{1}-s_{2}-2 t+c_{2}+c_{3}\right) \\
& x_{2}=(1 / 4 b)\left(a-s_{1}+3 s_{2}-2 t-3 c_{2}+c_{3}\right) \\
& x_{3}=(1 / 4 b)\left(a-s_{1}-s_{2}+2 t+c_{2}-3 c_{3}\right)
\end{aligned}
$$

Thus, as might be expected, the quantity sold by country 3 's firm increases with the tariff imposed by that country and decreases as the other countries increase their export subsidies, while the quantities sold by the other firms increase with the subsidy they receive and decrease as country 3 increases its tariff and the other exporting country increases its export subsidy.

Given the above results, the conditions for maximization of the countries' individual aggregate welfares through their trade policies are

$$
\begin{aligned}
\partial w_{1} / \partial s_{1} & =(1 / 8 b)\left(a-3 s_{1}-s_{2}-2 t+c_{2}+c_{3}\right)=0 \\
\partial w_{2} / \partial s_{2} & =(1 / 8 b)\left(a-s_{1}-3 s_{2}-2 t-3 c_{2}+c_{3}\right)=0 \\
\partial w_{3} / \partial s_{3} & =(1 / 8 b)\left(3 a+s_{1}+s_{2}-10 t-c_{2}-c_{3}\right)=0
\end{aligned}
$$

i.e. the countries' reaction functions are

$$
\begin{aligned}
& s_{1}=(1 / 3)\left(a-s_{2}-2 t+c_{2}+c_{3}\right) \\
& s_{2}=(1 / 3)\left(a-s_{1}-2 t-3 c_{2}+c_{3}\right) \\
& t=(1 / 10)\left(3 a+s_{1}+s_{2}-c_{2}-c_{3}\right)
\end{aligned}
$$


Thus the import duty imposed by country 3 increases to counteract the effects of increasing export subsidies and falling production costs in the other countries, both of which trends increase the profits of the other countries' firms and the incentive to extract revenue from them in the form of import duty (Brander and Spencer 1984). By contrast, the export subsidy of country 1 rises (with a consequent rise in the profits of country 1's firm) as rising costs and/or falling subsidization in the other countries reduce the profits of the other countries' firms and increase those of country 1's firm (with analogous behaviour by country 2 ). Increasing the export subsidies of either of countries 1 and 2 thus increases the diversion of profits from foreign firms to the domestic firm (Brander and Spencer 1985).

Solving eqs.9 affords the equilibrium subsidies and tariff:

$$
\begin{gathered}
s_{1 A}=(1 / 11)\left(a+9 c_{2}+3 c_{3}\right) \\
s_{2 A}=(1 / 11)\left(a-13 c_{2}+3 c_{3}\right) \\
t_{A}=(1 / 22)\left(7 a-3 c_{2}-c_{3}\right)
\end{gathered}
$$

As in the situations considered by Brander (1981) and Brander and Spencer (1984), both the tariff and the export subsidies are always positive so long as $a$ satisfies the conditions for positive market quantities imposed at the beginning of this section. Furthermore, the subsidy of country 1 is always greater than that of country 2 , since $s_{1 A}-s_{2 A}=2 c_{2}>0$. The welfare levels achieved when the equilibrium values of the policy instruments are established are

$$
\begin{aligned}
& W_{1 A}=(3 / 484 b)\left(a+9 c_{2}+3 c_{3}\right)^{2} \\
& W_{2 A}=(3 / 484 b)\left(a-13 c_{2}+3 c_{3}\right)^{2} \\
& W_{3 A}=(3 / 242 b)\left(34 a^{2}-15 a c_{2}-38 a c_{3}+15 c_{2}{ }^{2}-45 c_{2} c_{3}+64 c_{3}^{2}\right)
\end{aligned}
$$

\section{B. Formation of a preferential trade club as the result of non-cooperative behaviour in the absence of tariff uniformity}

In this situation, $n=0$ as before, but $t_{1}$ can differ from $t_{2}$. Analysis as above leads to the second-stage equilibrium:

$$
\begin{aligned}
& x_{1}=(1 / 4 b)\left(a+3 s_{1}-s_{2}-3 t_{1}+t_{2}+c_{2}+c_{3}\right) \\
& x_{2}=(1 / 4 b)\left(a-s_{1}+3 s_{2}+t_{1}-3 t_{2}-3 c_{2}+c_{3}\right) \\
& x_{3}=(1 / 4 b)\left(a-s_{1}-s_{2}+t_{1}+t_{2}+c_{2}-3 c_{3}\right)
\end{aligned}
$$

and the conditions for equilibrium in the first stage of the game are now

$$
\begin{aligned}
& \partial W_{1} / \partial s_{1}=(1 / 8 b)\left(a-3 s_{1}-s_{2}-3 t_{1}+t_{2}+c_{2}+c_{3}\right)=0 \\
& \partial W_{2} / \partial s_{2}=(1 / 8 b)\left(a-s_{1}-3 s_{2}+t_{1}-3 t_{2}-3 c_{2}+c_{3}\right)=0 \\
& \partial W_{3} / \partial t_{1}=(1 / 16 b)\left(3 a+9 s_{1}-7 s_{2}-21 t_{1}+11 t_{2}+7 c_{2}-c_{3}\right)=0 \\
& \partial W_{3} / \partial t_{2}=(1 / 16 b)\left(3 a-7 s_{1}+9 s_{2}+11 t_{1}-21 t_{2}-9 c_{2}-c_{3}\right)=0
\end{aligned}
$$


The equilibrium values of the policy instruments are

$$
\begin{aligned}
& s_{1 B}=(1 / 44)\left(4 a+3 c_{2}+12 c_{3}\right) \\
& s_{2 B}=(1 / 44)\left(4 a-19 c_{2}+12 c_{3}\right) \\
& t_{1 B}=(1 / 88)\left(28 a+21 c_{2}-4 c_{3}\right) \\
& t_{2 B}=(1 / 88)\left(28 a-45 c_{2}-4 c_{3}\right)
\end{aligned}
$$

Thus the possibility of country 3 discriminating tariff-wise between country 1 and country 2 is realized. In fact, since $t_{1 B}-t_{2 B}=3 c_{2} / 4>0$, country 3 places a greater tariff on the imports affording the greater profit to the exporter, in keeping with the relationship between exporters' profits and the non-discriminatory tariff $t$ of Section 3.1. This effective discrimination in favour of the exporting country with the higher costs amounts to the formation of a preferential trade club by countries 2 and 3.

The welfare levels resulting from application of the above policies are

$$
\begin{aligned}
& W_{1 B}=(3 / 7744 b)\left(4 a+3 c_{2}+12 c_{3}\right)^{2} \\
& W_{2 B}=(3 / 7744 b)\left(4 a-19 c_{2}+12 c_{3}\right)^{2} \\
& W_{3 B}=(3 / 3872 b)\left(544 a^{2}-240 a c_{2}-608 a c_{3}+603 c_{2}{ }^{2}-720 c_{2} c_{3}+1024 c_{3}{ }^{2}\right)
\end{aligned}
$$

Examination of the differences with respect to the preceding situation,

$$
\begin{aligned}
& W_{1 B}-W_{1 A}=\left(-9 c_{2} / 704 b\right)\left(8 a+39 c_{2}+24 c_{3}\right)<0 \\
& W_{2 B}-W_{2 A}=\left(9 c_{2} / 704 b\right)\left(8 a-71 c_{2}+24 c_{3}\right)>0 \\
& W_{3 B}-W_{3 A}=9 c_{2}^{2} / 32 b>0
\end{aligned}
$$

shows that country 1 is worse off and countries 2 and 3 are better off. Since $x_{3}$, $p_{3}, q$ and $p$ all turn out to be unchanged, the increase in $W_{3}$ is due exclusively to increased tariff income, the increase in the number of degrees of freedom inherent in discrimination between $t_{1}$ and $t_{2}$ having allowed country 3 to improve the optimization of its tariff structure. Countries 1 and 2 are worse off and better off, respectively, because country 1's firm sells less in market 3 while paying higher import duties, whereas country 2's firm sells more and pays lower duties. Assuming that country 3's policy is reciprocated by country 2 in regard to its own tariffs, the introduction of discriminatory tariffs can thus be seen as a strategy adopted by countries with higher costs to protect their markets against invasion by the producers of countries with lower costs.

\section{Results of formalization of a customs union}

If the benefits of mutual de facto preferential trade for countries 2 and 3 lead them to formalize economic integration as a customs union, then $t_{2}=0$ and $s_{2}=0$. Analysis as above leads to 


$$
\begin{gathered}
W_{1 C}=(1 / 75 b)\left(a+2 c_{3}\right)^{2} \\
W_{2 C}=(1 / 225 b)\left(4 a-10 c_{2}+3 c_{3}\right)^{2} \\
W_{3 C}=(1 / 150 b)\left(57 a^{2}-72 a c_{3}+25 c_{2}{ }^{2}-50 c_{2} c_{3}+103 c_{3}{ }^{2}\right)
\end{gathered}
$$

and

$$
W_{1 C}-W_{1 B}=\frac{4144 a^{2}-5400 a c_{2}+9736 a c_{3}-2025 c_{2}^{2}-16200 c_{2} c_{3}-1424 c_{3}^{2}}{580800 b}>0
$$

$$
W_{2 C}-W_{2 B}=
$$

$$
\frac{113104 a^{2}-516920 a c_{2}+121056 a c_{3}+530725 c_{2}^{2}-156840 c_{2} c_{3}-27504 c_{3}^{2}}{1742400 b}>0
$$

$$
W_{3 C}-W_{3 B}=\frac{-12048 a^{2}+54000 a c_{2}-2592 a c_{3}-87275 c_{2}^{2}+652000 c_{2} c_{3}-30992 c_{3}^{2}}{290400 b}
$$

Both the exporting countries are better off (because their firms' profits rise even when any subsidies are excluded from the accounts), but whether country 3 is better or worse off depends on whether the gain in consumer excess due to the growth of the market is or is not exceeded by the reduction of country 3's firm's profits together with the loss of tariff revenue

\section{Introduction of non-tariff barriers}

Let us now investigate whether the welfare that country 3 loses as the result of the formation of a formal customs union with country 2 can be regained through the introduction of non-tariff barriers $\left(t_{2}=s_{2}=0\right.$ but $n 1 / 40$ in equation 2). Analysis as before leads to the reaction functions

$$
\begin{gathered}
s_{1}=(1 / 3)\left(a-3 t_{1}-2 n+c_{2}+c_{3}\right) \\
t_{1}=(1 / 21)\left(3 a+9 s_{1}-2 n+7 c_{2}-c_{3}\right) \\
n=(1 / 6)\left(a+3 s_{1}+t_{1}-3 c_{2}+5 c_{3}\right)
\end{gathered}
$$

Note that, according to the third of these equations, if country 3 reduces its tariff on country 1's goods, it should also reduce its non-tariff barriers, in contradiction with the empirical observation that tariff reductions are generally accompanied by an increase in non-tariff barriers. We return to this point below.

Solving equations 19 affords

$$
s_{1 D}=(1 / 21)\left(a+3 c_{2}-c_{3}\right)
$$




$$
\begin{gathered}
t_{1 D}=(1 / 7)\left(a+3 c_{2}-c_{3}\right) \\
n_{D}=(1 / 14)\left(3 a-5 c_{2}+11 c_{3}\right)
\end{gathered}
$$

and these values of the policy instruments lead to the welfare levels

$$
\begin{aligned}
& W_{1 D}=(1 / 588 b)\left(a+3 c_{2}-c_{3}\right)^{2} \\
& W_{2 D}=(1 / 36 b)\left(a-3 c_{2}-c_{3}\right)^{2} \\
& W_{3 D}=(1 / 49 b)\left(17 a^{2}+4 a c_{2}-34 a c_{3}+6 c_{2}{ }^{2}-4 c_{2} c_{3}+17 c_{3}{ }^{2}\right)
\end{aligned}
$$

which differ from the levels prevailing before the introduction of non-tariff barriers by the amounts

$$
\begin{aligned}
& W_{1 D^{-}} W_{1 C}=(-1 / 4900 b)\left(57 a^{2}-50 a c_{2}+278 a c_{3}-75 c_{2}^{2}+50 c_{2} c_{3}+253 c_{3}^{2}\right)<0 \\
& W_{2 D^{-}} W_{2 C}=(-1 / 900 b)\left(39 a^{2}-170 a c_{2}+146 a c_{3}+175 c_{2}{ }^{2}-390 c_{2} c_{3}+11 c_{3}^{2}\right) \quad(22) \\
& W_{3 D^{-}} W_{3 C}=(-1 / 7350 b)\left(243 a^{2}-600 a c_{2}+1572 a c_{3}+325 c_{2}{ }^{2}-1850 c_{2} c_{3}+2497 c_{3}{ }^{2}\right)<0
\end{aligned}
$$

The introduction of non-tariff barriers thus reduces the welfare of both country 1 and country 3 (whether country 2 is better or worse off depends on the values of $a$ and $c_{2}$ relative to $c_{3}$ ). Country 3 therefore has no reason to introduce non-tariff barriers if it is really trying to maximize its welfare. However, closer analysis shows that although the introduction of non-tariff barriers both reduces tariff income and makes consumers worse off, the profits of country 3's firm increase. The empirical observation that a proliferation of non-tariff barriers does commonly accompany processes of trade liberalization in general and economic integration in particular therefore suggests that the governments of countries involved in such processes do not seek to maximize their country's aggregate welfare function but rather a distorted welfare function in which company profits are given more weight than consumer excess and tariff income.

Accordingly, let us suppose that country 3 has the distorted welfare function

$$
W_{3}{ }^{*}=U(q)-p q+t_{1} x_{1}+k \pi_{3}
$$

in which company profits are given weight $k>1$. Analysis as usual leads to

$$
\begin{aligned}
& s_{1}=(1 / 3)\left(a-3 t_{1}-2 n+c_{2}+c_{3}\right) \\
& t_{1}=[1 /(23-2 k)]\left[a(1+2 k)+s_{1}(11-2 k)-2 n(3-2 k)+c_{2}(5+2 k)+c_{3}(5-6 k)\right] \\
& n=[1 /(2+4 k)]\left[a(3-2 k)+t_{1}(3-2 k)+s_{1}(1+2 k)-c_{2}(1+2 k)-c_{3}(1-6 k)\right]
\end{aligned}
$$

Unlike the third of equations 19 , the third of equations 24 shows that when $k>3$ / 2 a reduction in country 3's tariff on country 1's goods should be accompanied by an increase in its non-tariff barriers, in agreement with the empirical observations.

This result supports the conclusion that a government introducing non-tariff barriers is not aiming to maximize the aggregate welfare of the country but rather a distorted welfare function that gives greater weight to company profits than to other components of welfare. 


\section{Conclusions}

In this paper, analysis of a simple model in which three countries with different production costs sell a homogeneous good in the market of the country with the highest production costs has led to three main conclusions. Firstly, although it is to the advantage of the importing country to form a preferential trading club with the country of intermediate costs by reducing the tariff on this country's goods, the formation of a customs union between these two countries is not to the importing country's advantage. Secondly, the importing country's loss of welfare due to the formation of a customs union is worsened if it introduces non-tariff barriers. Thirdly, the introduction of non-tariff barriers does increase the profits of the importing country's firm. Since it is observed empirically that processes of trade liberalization in general, and economic integration in particular, are commonly accompanied by the introduction of non-tariff barriers, the general conclusion is drawn that the governments of countries introducing such barriers apply a distorted welfare function so as to protect their producers.

\section{Acknowledgements}

This work was funded by the Xunta de Galicia, Spain, under Project PGIDT02PXI10001PR.

Received 29 April 2004, Accepted 1 July 2004

\section{References}

BRANDER, J. A. (1981), "Intra-Industry Trade In Identical Commodities", Journal Of International Economics, 11, 1-14.

BRANDER, J. A. y B. J. SPENCER (1984), "Trade Warfare: Tariffs And Cartels", Journal Of International Economics, 16, 227-242.

BRANDER, J. A. y B. J. SPENCER (1985), "Export Subsidies And International Market Rivalry Journal Of International Economics, 18, 83-100.

COLLIE, D. R. (1997). "Delegation and Strategic Trade Policy", International Economic Journal, 11, 35-46.

DALY, M. y H. KUWAHARA (1998), "The Impact Of The Uruguay Round On Tariff And Non-Tariff Barriers To Trade In The Quad", World Economy, 21 (2), 207-234. DALY, M. y S. STAMNAS (2001), "Tariff And Non-Tariff Barriers To Trade In Korea", 
Journal Of Economic Integration, 16 (4), 500-525.

GRETHER, J-M. and T. MÜLLER (2001), "Decomposing The Economic Costs And Benefits Of Accession To The EU: The Swiss Case" Journal Of Economic Integration, 18 (2), 203-228.

KEMP, M. C. y H. WAN (1976), "An Elementary Proposition Concerning The Formation Of Customs Unions", Journal Of International Economics, 6, 95-97.

LIPSEY, R. (1970), "The Theory Of Customs Unions: A General Equilibrium Analysis", London: L.S.E. Research Monograph.

NEVEN, J. y L. RÖLLER (1991), "European Integration And Trade Flows", European Economic Review, 35, 1295-1309.

RIEZMAN, R. (1985), "Customs Unions And Domestic Taxes”, Canadian Journal of Economics, 19, 353-365.

SANNA-RANDACCIO, F. (1996), "New Protectionism And Multinational Companies", Journal Of International Economics, 41, 29-51.

VINER, J. (1950), “The Customs Union Issue”, New York: Carnegie Endowment For International Peace.

WINKELMANN, L. y R. WINKELMANN (1997), "The Costs Of Non-Tariff Barriers To Trade: Evidence From New Zealand" Weltwirtschaftliches Archiv, 133(2), 270-281. YU, Z. (2000), "A Model Of Substitution Of Non-Tariff Barriers For Tariffs", Canadian Journal Of Economics, vol. 33, No4, November 2000, 1069-1090. 